\title{
Seberapa Jauh Aku Bisa Bangkit? Sebuah Studi mengenai Profil Resiliensi Psikologis Remaja Panti Asuhan
}

\author{
Bellatrix Dwi Rahmawati \\ Fakultas Psikologi, Universitas YARSI \\ bellatrixrahmawati@gmail.com \\ Ratih Arruum Listiyandini \\ Fakultas Psikologi, Universitas YARSI \\ ratih.arruum@gmail.com \\ Rina Rahmatika \\ Fakultas Psikologi, Universitas YARSI \\ rina.rahmatika@gmail.com
}

\begin{abstract}
The purpose of this research is to describe the profile and level of psychological resilience of adolescents living at social shelter. This research is using quantitative, cross-sectional design, descriptive approach and the population is adolescents who live at social shelter in Jakarta and Bekasi. Due to the explorative nature of this study and lack of the acurate data about total amount the teenagers, the sample of this research is taken by using convenience sampling technique across 12 Social Shelter in Jakarta and Bekasi. The sample of the study is 200 Adolescents. Adapted scale of resilience by Connor - Davidson was used for measure resilience level and descriptive statistic was used for the analysis. The result of this research found that $46.5 \%$ of participants have high resilience and $52.5 \%$ has moderate level of resilience. Whereas, only $1 \%$ who has low level of resiliences. Based on the analysis from each dimension, the highest dimension of resilience is in the domain of "Personal Competence" and the lowest one is on "Tolerance of Negative Affect". This result implied that to developing resilience program for adolescents at social shelter, it is needed to help them develop their ability to overcome the negative affect.
\end{abstract}

Keywords: resilience; psychological; adolescents; social shelter

\section{Abstrak}

Penelitian ini bertujuan untuk menjelaskan mengenai profil dan tingkat resiliensi psikologis pada remaja di panti asuhan. Penelitian ini merupakan studi dalam bentuk deskriptif, cross-sectional, kuantitatif dan populasi penelitian yang dituju adalah remaja panti asuhan di wilayah Jakarta dan Bekasi. Dikarenakan sifat studi yang 
eksploratif dan tidak adanya data yang akurat mengenai total jumlah remaja panti asuhan, maka sampel dalam penelitian ini diambil dari 12 panti asuhan yang ada di wilayah Jakarta dan Bekasi menggunakan teknik convenience sampling. Sampel diperoleh sebanyak 200 orang remaja. Penelitian menggunakan adaptasi dari skala resiliensi Connor-Davidson dan uji analisis statistik yang digunakan adalah statitistik deskriptif. Hasil penelitian menunjukkan bahwa remaja di panti asuhan yang memiliki resiliensi tergolong tinggi adalah sebesar 46,5\% dan yang tergolong sedang adalah 52,5\%, sedangkan hanya $1 \%$ yang memiliki resiliensi tergolong rendah. Berdasarkan hasil analisis deskriptif dari setiap dimensi resiliensi, juga didapatkan bahwa remaja di panti asuhan memiliki resiliensi yang paling tinggi pada dimensi 'Kompetensi Personal' dan terendahnya adalah pada dimensi 'Toleran Terhadap Afek Negatif'. Hasil penelitian ini memiliki implikasi bahwa dalam pengembangan program-program resiliensi bagi remaja di panti asuhan penting untuk memberi perhatian pada peningkatan kemampuan dalam mengatasi emosi negatif dalam diri mereka.

Kata Kunci: resiliensi; psikologis; remaja; panti asuhan

\section{Pendahuluan}

Panti asuhan merupakan lembaga yang memberikan pelayanan pengganti orang tua atau keluarga untuk anak dan bertanggung jawab dalam memenuhi kebutuhan fisik, mental, dan sosial kepada anak asuh (Depsos RI, dalam Armis, 2016). Beberapa faktor yang menyebabkan anak-anak harus rela berpisah dengan keluarganya sehingga berada di sebuah panti asuhan, seperti ekonomi yang rendah, menjadi yatim, piatu, atau bahkan yatim piatu (Hartini, dalam Tricahyani,2016). Oleh karena itu, mereka yang tinggal di panti asuhan adalah kelompok yang perlu untuk diberi perhatian. Terutama pada masa remaja yang merupakan masa pencarian jati diri, dibutuhkan adanya dukungan bagi mereka untuk tetap bisa berkembang dengan sehat.

Menurut Departemen Sosial (2016), peran panti asuhan belum dapat menggantikan peran orang tua dalam keluarga serta fungsi keluarga. Dalam hal ini, ditemukan bahwa panti asuhan tidak memberikan pengasuhan sama sekali, melainkan hanya memberikan akses pendidikan saja (Depsos, 2016). Kurangnya fungsi pengasuhan di panti asuhan, terlihat dari kurangnya dukungan emosional 
dikarenakan jumlah pengasuh tidak sebanding dengan jumlah anak di panti asuhan. Kondisi ini menyebabkan anak di panti asuhan menjadi kurang mendapatkan kasih sayang, perhatian dan bimbingan secara mendalam serta penurunan pencapaian akademik (Rifai, 2014; Yendork \& Somhlaba, 2014). Perilaku teman-teman yang sering memicu pertengkaran juga menyebabkan remaja panti asuhan menarik diri dan sulit menjalin hubungan sosial dengan orang lain, sehingga memiliki masalah sosial di sekolah, baik dengan teman maupun guru (Tsuraya, 2017). Mereka juga menjadi kurang dapat berekspresi karena adanya peraturan yang harus ditaati. Selain itu, terdapat pula permasalahan fisik yang dialami remaja yang tinggal di panti asuhan yaitu terjadinya penyakit menular seperti cacar, influenza maupun gatal-gatal dan kurangnya aktivitas fisik seperti olahraga sehingga menyebabkan kondisi kesehatan yang kurang baik (Dewi, 2016).

Kondisi di panti asuhan yang kurang memadai tersebut dapat menimbulkan beberapa dampak negatif yang mengikutinya (Tsuraya, 2017). Ditemukan bahwa remaja yang tinggal di panti asuhan memiliki kecenderungan untuk mudah stres maupun depresi, serta lebih rentan mengalami berbagai macam tekanan dan permasalahan daripada remaja pada umumnya yang masih memiliki keluarga yang utuh. Hasil penelitian yang dilakukan oleh Hartini (dalam Tricahyani, 2016) juga menemukan bahwa remaja panti asuhan memiliki kepribadian yang inferior, pasif, apatis, menarik diri, mudah putus asa, penuh dengan ketakutan, dan kecemasan dibandingkan pada remaja yang memiliki keluarga yang utuh.

Untuk menghadapi kondisi hidup di panti asuhan, dibutuhkan kemampuan untuk bangkit kembali yang dikenal dengan istilah resiliensi. Menurut Connor dan Davidson (2003) resiliensi didefinisikan sebagai kualitas personal seseorang yang memungkinkan untuk berkembang dalam menghadapi kesulitan dalam hidupnya. Individu yang resilien akan lebih tahan terhadap stres sehingga lebih sedikit mengalami gangguan emosi dan perilaku (Hauser, dalam Aisha 2014). Connor dan Davidson (2003), mengidentifikasi lima aspek dari resiliensi, yaitu, kompetensi 
personal, standar yang tinggi dan keuletan, percaya kepada diri sendiri, memiliki toleransi terhadap afek negatif dan kuat dalam menghadapi tekanan, penerimaan positif terhadap perubahan, hubungan yang baik dengan orang lain, pengendalian diri, dan spiritualitas.

Secara umum, resiliensi sangat penting bagi remaja karena perubahan sosial, biologis, dan psikologis yang dialami remaja menuntut mereka untuk adaptif dalam menghadapi masalah (Khabbaz., Behjati \& Naseri, 2011; Athigi., Athigi \& Atighi, 2015). Penelitian sebelumnya juga menemukan bahwa karakteristik yang membentuk resiliensi dapat berhubungan atau mempengaruhi kualitas hidup remaja. Misalnya, penelitian yang dilakukan oleh Mannix, dkk (2009) yang menyatakan apabila seorang remaja penderita kanker memiliki rasa optimis yang tinggi, semakin tinggi juga kualitas hidupnya. Tingginya kualitas hidup disertai oleh berkurangnya rasa sakit, bisa berkomunikasi dengan baik, serta memiliki fungsi psikologis yang tinggi pula.

Resiliensi merupakan interaksi antara protective factor (faktor pendukung) dan risk factor (faktor risiko) (Ahern, 2006). Istilah protective factor dalam resiliensi merupakan faktor - faktor yang membantu dan mendukung untuk bangkit dan pulih dari kesulitan yang dihadapi (Fara, 2012) seperti faktor individual, faktor keluarga, faktor komunitas dan faktor budaya. Sebaliknya, faktor risiko adalah peristiwa, kondisi, atau pengalaman yang dapat meningkatkan kemungkinan terbentuknya, terjaga atau diperburuknya suatu masalah (Fraser \& Terzian, dalam Jenson \& Frazer 2010). Menurut Neill \& Dias (2001), ada beberapa hal yang termasuk faktor risiko yaitu kematian orang tua/perceraian, ekonomi rendah, serta hidup di lingkungan negatif. Remaja yang tinggal di panti asuhan merupakan kelompok remaja yang memiliki kerentanan karena adanya faktor resiko dalam hal kehilangan sosok orangtua kandung, berada dalam tingkat sosial ekonomi rendah, dan hidup di lingkungan yang kurang suportif. Dengan demikian, menjadi penting untuk menelaah mengenai tingkat resiliensi pada remaja di panti asuhan dalam rangka memetakan kebutuhan mereka akan perkembangan psikologis yang lebih baik. 
Pada remaja yang tinggal di panti asuhan, resiliensi penting untuk membantu mereka dapat bangkit dari kenyataan yang tidak diinginkan atau suatu kondisi yang membuatnya tertekan, seperti kondisi kehilangan orang tua dan masalah ekonomi, sehingga mereka dapat menjalankan hidupnya dengan lebih produktif (Tsuraya, 2017). Individu dapat dikatakan resilien saat mampu untuk menghargai diri sendiri, mencari seseorang untuk berbagi ketika ia membutuhkannya dan mencari kekuatan positif untuk bangkit dari masalah (Shatte, dalam Ifdil \& Taufik, 2012).

Terdapat beberapa penelitian terdahulu mengenai resiliensi pada remaja panti asuhan. Penelitian sebelumnya menemukan bahwa remaja yang tinggal di rumah memiliki resiliensi yang tinggi dibandingkan remaja yang tidak tinggal di rumah (Kaur \& Rani, 2015). Ditemukan pula bahwa remaja panti asuhan lebih rentan terhadap risiko resiliensi yang dapat menyebabkan depresi, keputusasaan, dan trauma psikologis di kemudian hari (Coombe, 2003).

Untuk mengetahui fenomena dan gambaran resiliensi pada remaja di panti asuhan, peneliti juga melakukan studi awal dengan memberikan kuesioner berupa pernyataan dalam bentuk jawaban ya/tidak kepada 12 orang remaja yang tinggal di sebuah Panti Asuhan yang berada di Bekasi. Dari hasil analisis, ditemukan bahwa $80 \%$ remaja panti asuhan tidak bisa tenang pada saat situasi yang menekan sehingga mudah merasa cemas dan stres. Selain itu, dari hasil wawancara dengan salah satu subjek didapatkan bahwa ia merasa kesulitan-kesulitan yang dialaminya seringkali membuatnya sedih, mudah marah, tidak percaya diri bahkan putus asa. Mereka juga merasa takut apabila berhubungan sosial dengan orang lain. Namun di sisi lain, terdapat subjek yang bisa tenang ketika menghadapi masalah dan mengekspresikannya dengan menulis buku diary atau bercerita ke temannya. Penemuan awal ini dapat mengindikasikan gambaran resiliensi yang beragam pada remaja panti asuhan.

Penelitian ini bertujuan untuk menjelaskan mengenai tingkat dan gambaran resiliensi psikologis pada remaja di panti asuhan. Penelitian akan dilakukan pada 
remaja panti asuhan di wilayah Jakarta dan Bekasi, dengan pertimbangan bahwa Jakarta dan Bekasi merupakan kota besar yang memiliki jumlah panti asuhan kurang lebih sebesar 1,200 (Komnas PA, 2018).

\section{Metode}

Penelitian ini metode kuantitatif dengan tipe penelitian deskriptif. Variabel dalam penelitian ini adalah Resiliensi. Populasi dalam penelitian ini adalah remaja panti asuhan yang tinggal menetap di panti asuhan dengan rentang usia 11-18 tahun di Jakarta dan Bekasi dengan subjek penelitian berjumlah 200 subjek. Dari 200 orang partisipan, sebagian besar adalah laki-laki (50,5\%) dan perempuan $(49,5 \%)$, rata-rata usia subjek adalah $(\mu=14,77)$, dan memiliki rata-rata tingkat pendidikan saat ini yaitu SMP (52\%). Selain itu, sebagian besar penyebab subjek penelitian tinggal di panti asuhan dikarenakan kondisi ekonomi keluarga (58\%).

Tabel 1 Deskripsi Diri Subjek Penelitian

\begin{tabular}{ccc}
\hline Variabel & Jumlah & Persentase \\
\hline Jenis Kelamin & & \\
Perempuan & 99 & $49,5 \%$ \\
Laki-Laki & 101 & $50,5 \%$ \\
\hline Usia ( $\boldsymbol{\mu = 1 4 , 7 7 )}$ & & \\
11-15 Tahun & 123 & $61,5 \%$ \\
16-18 Tahun & 77 & $38,5 \%$ \\
\hline Penyebab Tinggal Dipanti & & \\
Orangtua Meninggal & 74 & $37 \%$ \\
Kondisi Ekonomi & 116 & $58 \%$ \\
Lain-lainnya & 10 & $5 \%$ \\
\hline Tingkat Pendidikan & & \\
SD & 20 & $10,0 \%$ \\
SMP & 104 & $52,0 \%$ \\
SMA/SMK & 76 & $38,0 \%$ \\
\hline
\end{tabular}

Variabel resiliensi diukur dengan menggunakan alat ukur CD-RISC (Connor Davidson Resilience Scale) yang dikembangkan oleh Connor dan Davidson (2003) dengan memiliki nilai cronbanch' $\alpha=0.89$ dan korelasi antara aitem dengan skor total berkisar $0,30-0,70$. 
Alat ukur CD-RISC yang digunakan oleh peneliti sudah melalui proses adaptasi (Mujahidah \& Listiyandini, 2018). Dalam proses adaptasi alat ukur, terdapat proses backtranslation, expert judgement, uji keterbacaan, serta uji coba. Koefisien reliabilitas yang pernah di ujicoba terakhir kali adalah pada sampel remaja umum yang memiliki corrected item total correlation sebesar 0,3 - 0,5 dan koefisien reliabilitas sebesar $\alpha=0,88$ (Mujahidah \& Listiyandini, 2018). Pada penelitian ini melakukan uji coba kembali terhadap 157 remaja umum dengan hasil nilai reliabilitas yang baik yaitu sebesar 0,952 dan memiliki rentang validitas aitem sebesar 0,485 0,765. Secara keseluruhan aitem pada alat ukur ini dianggap valid dan layak digunakan karena memiliki koefisien korelasi pada kolom corrected item total correlation diatas 0,2 (Nisfiannoor, 2009). Berdasarkan nilai tersebut, maka alat ukur dapat dikatakan reliabel dan dapat digunakan dalam penelitian.

Tabel 2. Contoh Item Skala CD-RISC

\begin{tabular}{ll}
\hline \multicolumn{1}{c}{ Dimensi } & \multicolumn{1}{c}{ Contoh Aitem } \\
\hline Kompetensi personal, standar yang tinggi, dan keuletan & $\begin{array}{l}\text { - Saya bekerja untuk mencapai tujuan } \\
\text { - Saya yakin dapat meraih tujuan }\end{array}$ \\
\hline $\begin{array}{l}\text { Percaya pada diri sendiri, memiliki toleransi terhadap } \\
\text { afek negative dan kuat dalam menghadapi tekanan }\end{array}$ & $\begin{array}{l}\text { - Saya harus bertindak sesuai firasat } \\
\text { - Saya mampu membuat keputusan } \\
\text { yang sulit }\end{array}$ \\
\hline $\begin{array}{l}\text { Menerima positif terhadap perubahan dan hubungan yang } \\
\text { baik dengan orang lain }\end{array}$ & $\begin{array}{l}\text { - Saya mampu untuk menyesuaikan diri } \\
\text { terhadap perubahan }\end{array}$ \\
& $\begin{array}{l}\text { - Saya menjalin hubungan yang dekat } \\
\text { dan nyaman bersama orang lain }\end{array}$ \\
\hline Pengendalian diri & - Saya dapat mengendalikan hidup \\
& $\begin{array}{l}\text { - Saya tahu dimana harus meminta } \\
\text { pertolongan }\end{array}$ \\
\hline Pengaruh spiritual & - Terkadang saya merasa takdir tuhan \\
& dapat menolong \\
\hline
\end{tabular}

\section{Hasil dan Pembahasan}

\section{Uji Normalitas Data}

Berdasarkan pada tabel 3, dapat diketahui bahwa hasil uji normalitas data menggunakan Kolmogorov Smirnov ditemukan bahwa data dalam penelitian ini 
berdistribusi normal pada variabel resiliesni karena memiliki nilai signifikansi $\mathrm{p}>0,05$.

\section{Tabel 3. Hasil Uji Normalitas}

\begin{tabular}{lcc}
\hline Variabel & Kolmogorov-Smirnov Z & Sig. (2-tailed) \\
\hline Resiliensi & 0,806 & 0,534 \\
\hline Keterangan : Sig. $(p>0,05)$ &
\end{tabular}

\section{Kategorisasi Resiliensi}

Berikut ini akan dijelaskan deskripsi umum skor resiliensi remaja panti asuhan. Data ini penting dalam pengolahan data untuk mengkategorikan subjek ke dalam tiga kelompok subjek yang dimaksudkan. Deskripsi umum skor maksimum, minimum, mean, dan standar deviasi resiliensi remaja panti asuhan dapat dilihat pada tabel 4.

Tabel 4. Deskripsi Umum Resiliensi

\begin{tabular}{cccccc}
\hline Variabel & N & Min & Maks & Mean & St. Deviasi \\
\hline Resiliensi & 200 & 3 & 97 & 66,54 & 14,067 \\
\hline
\end{tabular}

Remaja panti asuhan kemudian dikategorikan memiliki resiliensi tinggi, sedang atau rendah berdasarkan masing-masing skor total resiliensi subjek. Berdasarkan standar acuan pembagian skor menurut Azwar (2015) yang menggunakan skor total dari variabel resiliensi, maka resiliensi remaja panti asuhan dikategorikan sebagai berikut:

Tabel 5. Kategori Data Variabel Resiliensi

\begin{tabular}{cccc}
\hline Kategorisasi & Rentang Skor & Total & Percentase \\
\hline Rendah & $0-33$ & 2 & $1,0 \%$ \\
Sedang & $34-67$ & 105 & $52,5 \%$ \\
Tinggi & $68-100$ & 93 & $46,5 \%$ \\
\hline & Jumlah & 200 & $100 \%$ \\
\hline
\end{tabular}

\section{Profil Resiliensi berdasarkan Dimensi}

Dari tabel 4 dapat dilihat bahwa remaja panti asuhan yang memiliki resiliensi tergolong sedang yaitu sebanyak 105 orang (52,5\%), dengan resiliensi yang tergolong tinggi sebanyak 93 orang (46,5\%), dan remaja panti asuhan yang tergolong kedalam 
kemampuan resiliensi rendah sebanyak 2 orang (1\%). Gambaran resiliensi remaja panti asuhan dapat dilihat berdasakan lima aspek resiliensi. Berikut grafik berdasarkan rata-rata konversi setiap aspek-aspek resiliensi.

Grafik 1. Rata-rata Aspek-aspek Resiliensi

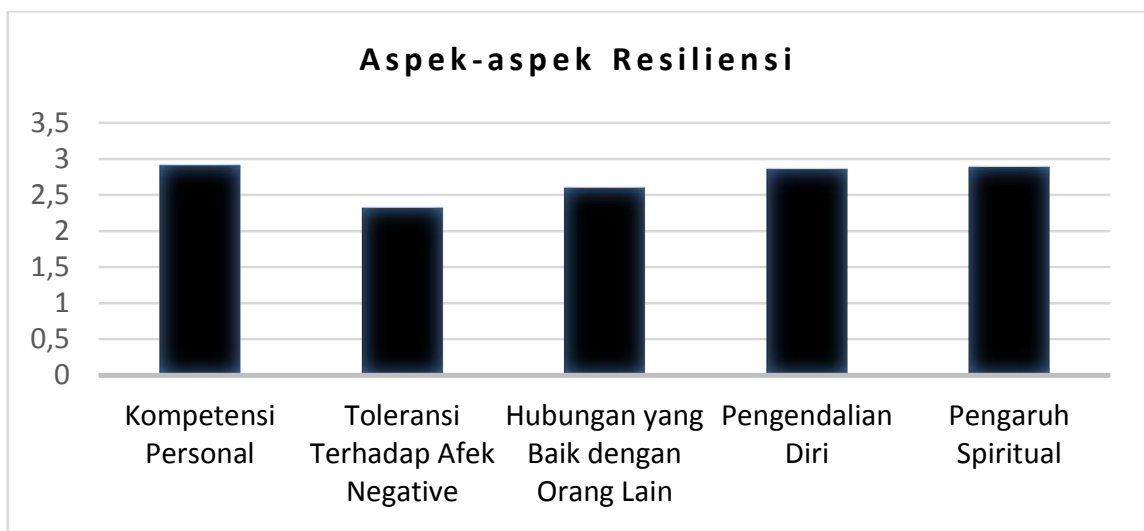

Berdasarkan hasil analisis statistik didapatkan bahwa remaja panti asuhan memiliki resiliensi yang tinggi pada aspek kompetensi personal $(\mu=2,91 ; \sigma=$ $0,65003)$ dan terendahnya pada aspek toleransi terhadap afek negatif $(\mu=2,32, \sigma=$ $0,67327)$.

\section{Hasi Uji Beda Resiliensi berdasarkan Faktor-Faktor Demografis}

Berikut hasil uji beda antara resiliensi dengan faktor demografi yang memiliki pengaruh dengan resiliensi.

\section{Tabel 6. Hasil Uji Beda}

\begin{tabular}{cc}
\hline Variabel & Sig. (2-tailed) \\
\hline Usia & $\mathrm{t}=-2,792$ \\
& $(\mathrm{p}=0,006)^{* *}$ \\
$\mathrm{t}=-1,390$ \\
Jenis Kelamin & $(\mathrm{p}=0,166)$ \\
& $\mathrm{F}=2,626$ \\
Tingkat Pendidikan & $(\mathrm{p}=0,075)$ \\
\hline
\end{tabular}

Berdasarkan hasil analisis uji beda demografis dengan resiliensi pada tabel 6 memperlihatkan bahwa adanya perbedaan yang signifikan pada resiliensi $(t=-1,390$, $\mathrm{p}<0,05)$ jika ditinjau dari jenis kelamin. 


\section{Diskusi}

Hasil penelitian yang telah dilakukan pada 200 remaja yang tinggal di 12 panti asuhan yang tersebar di Jakarta dan Bekasi didapatkan hasil bahwa proporsi laki-laki lebih banyak dibandingkan perempuan yaitu responden laki-laki berjumlah 101 subjek (50,5\%) sedangkan perempuan berjumlah 99 subjek (49,5\%). Usia subjek rata-rata 14,77 tahun dengan mayoritas pendidikan subjek saat dilakukan penelitian adalah SMP/MTS. Pada penelitian ini ada beberapa faktor yang menyebabkan mereka tinggal di panti asuhan, sebagian besar penyebab dikarenakan dari keluarga dengan ekonomi yang rendah berjumlah 116 subjek (58\%) dan kedua orang tua meninggal berjumlah 74 subjek (37\%). Selain itu, pada penelitian ini ditemukan juga bahwa mereka yang tinggal di panti asuhan dikarenakan di usir oleh kedua orang tuanya, ingin hidup mandiri dan tinggal di jalanan (5\%).

Remaja panti asuhan memiliki berbagai risiko dan masalah dalam perkembangannya, seperti memiliki kecenderungan untuk mudah stres maupun depresi, serta lebih rentan mengalami berbagai macam tekanan dan permasalahan (Hartini, dalam Tricahyani, 2016). Dalam mengatasi permasalahannya mereka perlu untuk tetap yakin mampu bertahan hidup dan melanjutkan sekolahnya. Adanya faktor pendukung (protective factors) dari dalam diri maupun luar diri seperti minat, motivasi, dukungan dari teman-teman panti dan pengasuh, faktor komunitas dan budaya (Isaacson, 2002; Olsson, dkk., 2003; ClaussEhlers, dkk., 2006; Everal, dkk dalam Fara, 2012) bisa menciptakan kesempatan yang baik bagi perkembangan remaja. Interaksi antara faktor pendukung dan faktor risiko merupakan yang menciptakan resiliensi.

Resiliensi ialah sebuah kualitas personal seseorang yang memungkinkannya untuk berkembang dalam menghadapi kesulitan dalam hidup. Dengan kualitas personalnya yang dimilikinya, diharapkan individu yang mengalami kesulitan dalam hidup dapat bangkit dan tidak kalah dengan keadaan (Connor \& Davidson, 2003). Resiliensi membantu remaja dapat bangkit atau pulih dari kesulitan yang dihadapinya sehingga dapat menghilangkan stressornya (Fara, 2012). Dengan adanya resiliensi 
pada remaja panti asuhan, risiko dari tekanan-tekanan dan risiko buruk yang membahayakan dapat dihindari karena resiliensi akan membantu melindungi untuk mampu bertahan serta bangkit dari masalah yang dialaminya (Napitupulu, 2009).

Berdasarkan hasil penelitian menunjukkan secara umum remaja panti asuhan memiliki tingkat resiliensi yang tergolong rendah dan sedang dengan total $53.5 \%$, dibandingkan yang tergolong tinggi $46.5 \%$. Penelitian ini tidak sejalan dengan penelitian yang dilakukan oleh Hidayati (2014) yang menyatakan bahwa remaja di panti asuhan keluarga yatim (PAKYM) memiliki kategori tinggi sebesar 76\%. Hal ini dikarenakan adanya faktor internal maupun eksternal yang mempengaruhi tingkat resiliensi. Faktor internal yang berpengaruh pada resiliensi, terdiri atas komunikasi dan kerjasama, self-esteem, empati, help seeking behavior, dan tujuan dan aspirasi, sedangkan yang termasuk faktor eksternal adalah dukungan keluarga, dukungan sekolah, dukungan masyarakat, autonomy experience, partisipasi dalam kegiatan ekstrakurikuler (Sun \& Stewart, 2007; Everal, dkk dalam Fara, 2012).

Berdasarkan hasil perhitungan rata-rata skor konversi per-aspek didapatkan bahwa remaja panti asuhan memiliki kemampuan yang rendah pada toleransi terhadap afek negatif $(\mu=2.32)$. Hal ini sesuai dengan hasil wawancara pada studi awal bahwa remaja panti asuhan tidak dapat tenang dalam situasi yang menekan sehingga mudah merasa cemas dan stress. Pada aspek ini berhubungan dengan ketenangan dalam bertindak, dimana individu yang tenang cenderung berhati-hati dalam mengambil sikap atas masalah yang dihadapi serta individu cepat melakukan coping terhadap stres, dan tetap fokus sekalipun sedang dalam menghadapi masalah (Connor \& Davidson, 2003). Apabila remaja memiliki aspek ini akan bermanfaat untuk lebih mudah menjalin hubungan dengan orang dan terhindar dari gangguan emosi dan perilaku (Fabes, dkk, 2006; Parke, dkk, 2006). Hal ini sejalan dengan penelitian yang dilakukan oleh Morelen dan Zeman (dalam Nurmalita \& Hidayati, 2014) yang menyatakan bahwa regulasi emosi pada remaja yang tinggal di panti asuhan lebih rendah dibandingkan dengan remaja yang tinggal dengan orang tua serta remaja yang tinggal di panti asuhan lebih rentan untuk mengalami masalah gangguan 
emosional dan kesejahteraan psikologis. Dalam melakukan regulasi emosi remaja panti asuhan lebih suka bereaksi negatif terhadap situasi stres dalam hidup mereka dengan menyalahkan diri sendiri, denial, dan behavioral disengagement (Mohammadzadeh, dkk, 2018). Hasil wawancara pada studi awal penelitian dengan beberapa subjek didapatkan bahwa ia merasa kesulitan-kesulitan yang dialaminya seringkali membuatnya sedih, mudah marah, tidak percaya diri bahkan putus asa.

Sebaliknya, ditemukan bahwa remaja panti asuhan mempersepsi memiliki kompetensi personal $(\mu=2.91)$ yang lebih baik dibandingkan dimensi lainnya. Pada aspek ini menjelaskan tentang kompetensi personal individu dimana individu merasa sebagai orang yang mampu untuk mencapai tujuan walaupun dalam situasi kemunduran atau kegagalan. Individu ketika mengalami tekanan atau stres cenderung merasa ragu akan berhasil dalam mencapai tujuan sehingga dibutuhkan standar yang tinggi dan keuletan dalam diri individu tersebut. Tingginya kompetensi personal pada remaja panti asuhan menunjukkan bahwa ketika mereka memiliki permasalahan, mereka tetap yakin dan berusaha bangkit dari permasalahan yang menimpanya sehingga mereka tetap berhasil sesuai dengan tujuan yang mereka ingin capai. Penelitian ini didukung oleh penelitian sebelumnya yang menyatakan bahwa remaja panti asuhan memiliki salah satu karakteristik resiliensi yaitu optimisme, dimana optimisme remaja panti asuhan menunjukkan pada kategori yang tinggi (Shabrina \& Nugraha, 2018). Ketika remaja panti asuhan menghadapi sebuah tantangan, apabila terdapat rasa optimisme dalam diri, mereka akan terus memperjuangkan usahanya untuk dapat keluar dari situasi yang sulit (Carver \& Scheier, 2012).

Ditemukan bahwa remaja awal dan remaja akhir memiliki perbedaan yang signifikan pada resiliensi. Penelitian ini menemukan bahwa remaja akhir memiliki rata-rata $(\mu=69,99)$ yang signifikan lebih tinggi $(\mathrm{t}=-2,792, \mathrm{p}=0,006)$ dibandingkan dengan dibandingkan dengan remaja awal $(\mu=64,37)$. Hasil tersebut sejalan dengan penelitian Freisen (2005) terdapat perbedaan resiliensi berdasarkan usia. Hal ini dikarenakan bahwa semakin matang usia seseorang maka semakin tinggi tingkat resiliensinya. 


\section{Kesimpulan dan Saran}

\section{Kesimpulan}

Berdasarkan hasil penelitian yang telah dilakukan, tingkat resiliensi psikologis pada remaja panti asuhan ditemukan berada pada tergolong sedang hingga tinggi. Remaja panti asuhan memiliki kemampuan paling rendah pada aspek toleransi terhadap afek negatif dan memiliki kemampuan yang tinggi pada aspek kompetensi personal.

\section{Saran}

Remaja panti asuhan agar dapat menjadi seorang yang resilien tetap harus mengembangkan tingkat resiliensinya dengan optimal karena resiliensi merupakan pondasi dari semua karakter positif dalam membangun kekuatan emosional dan psikologis remaja. Mengingat pentingnya resiliensi pada remaja di panti asuhan, pengelola panti asuhan dapat membuat pelatihan terkait resiliensi untuk meningkatkan tingkat resiliensinya serta lebih memperhatikan kesejahteraan remaja di panti asuhan dan peduli pada keadaan remaja di panti. Bagi remaja panti asuhan, disarankan untuk mengembangkan resiliensi untuk mengatasi permasalahan pada setiap aspek kehidupan terutama pada regulasi emosi dimana remaja panti asuhan dapat memilih coping yang lebih positif.

Selama proses penelitian ini, peneliti menyadari masih terdapatnya kekurangan atau keterbatasan pada proses penelitian yang dilakukan. Dalam penelitian ini, penelitian ini merupakan penelitian yang bersifat deskriptif kuantitatif, sehingga terdapat beberapa data yang tidak dapat diungkapkan dengan menggunakan jenis ini. Akan sangat menarik untuk penelitian selanjutnya diharapkan menggunakan jenis penelitian kualitatif terhadap subjek penelitian. Selain itu, desain penelitian yang bersifat cross-sectional dapat dikembangkan lagi menjadi penelitian longitudinal. Dalam penelitian ini juga, peneliti kurang mengontrol hal-hal yang terjadi selama pengambilan sampel. Sampel yang diambil sebagian besar adalah remaja panti asuhan yang berasal dari keluarga miskin dan peneliti tidak mengkhususkan remaja panti asuhan dengan kondisi pengalaman traumatis yang signifikan, yaitu mereka yang 
benar-benar kehilangan kedua orangtua. Oleh karena itu, dalam penelitian selanjutnya dengan tema yang berkaitan dengan resiliensi pada remaja panti asuhan, sebaiknya mampu mengungkap lebih dalam mengenai resiliensi di panti asuhan dan setiap aspeknya dengan menggunakan penelitian kualitatif yang bersifat longitudinal dan memilih subjek penelitian lebih spesifik seperti remaja panti asuhan yatim piatu.

\section{DAFTAR PUSTAKA}

Ahern, N., Kiehl, E., Sole, M., \& Byers, J. (2006). A Review of Instrument Measuring Resilience. Issues in Comprehensive Pediatric Nursing, 29, 103-125.

Aisha, D. L. (2014). Hubungan Antara Religiusitas Dengan Resiliensi Pada Remaja Di Panti Asuhan Keluarga Yatim Muhammadiyah Surakarta. (Skripsi). Fakultas Psikologi Universitas Muhammadiyah Surakarta: Surakarta.

Armis, A. (2016). Manajemen Panti Asuhan At-Taqwa Muhammadiyah dalam Membina Kepribadian Siswa MTS Muhammadiyah Padang Luar Kecamatan Rambatan Kabupaten Tanah Datar. Al-Fikrah, 3(2), 137-146.

Atighi, E., Atighi, A., \& Atighi, I. (2015). Predicting Psychological Resilience Based on Parenting Styles in Girl Adolescence. International Research Journal of Applied and Basic Sciences, 9(8), 1340-1344.

Azwar, S. (2015). Reliabilitas dan validitas. Yogyakarta: Pustaka Pelajar.

Carver, C. S., \& Scheier, M. F. (2012). Attention and self-regulation: A control theory approach to human behavior. Springer Science \& Business Media.

Clauss-Ehlers, C. S. (2008). Sociocultural factors, resilience, and coping: Support for a culturally sensitive measure of resilience. Journal of Applied Developmental Psychology, 29(3), 197-212.

Coombe, C. 2003. Consultation on HIV/AIDS and teacher education in East and Southern Africa. Paper presented at Kopanong Conference Centre, Johannesburg. 
Connor, K. M., \& Davidson, J. R. (2003). Development of a new resilience scale: The Connor-Davidson resilience scale (CD-RISC). Depression and anxiety, 18(2), 76-82.

Dewi, N. A. A. (2016). Pengaruh Pendidikan Kesehatan Tentang Perilaku Hidup Bersih Dan Sehat (Phbs) Dengan Metode Ceramah Terhadap Pengetahuan Dan Sikap Pada Anak Panti Asuhan Keluarga Yatim Muhammadiyah Surakarta. (Skripsi). Fakultas Ilmu Kesehatan Universitas Muhammadiyah Surakarta: Surakarta.

Fara, E. (2012). Resiliensi pada dewasa awal berlatar belakang budaya aceh yang mengalami bencana tsunami 2004. (Skripsi). Fakultas Psikologi Universitas Indonesia: Depok.

Fabes, R.A., Gaertner, B.M., Popp, T.K. (2006). Getting along with others: social competence in early childhood. Early Childhood Development, 15, 297316.

Freisen, B. J. (2005). Resilience and Recovery: Findings from thekauai longitudinal study. Research, Policy, and Practice in Children's Mental Health Summer, 19(1), 11-14.

Hidayati, N. L. (2014). Hubungan antara self-esteem dengan resiliensi pada remaja di Panti Asuhan Keluarga Yatim Muhammadiyah Surakarta. (Skripsi). Fakultas Psikologi Universitas Muhammadiyah Surakarta: Surakarta.

Ifdil, I., \& Taufik, T. (2012). Urgensi Peningkatan dan Pengembangan Resiliensi Siswa di Sumatera Barat. Pedagogi, 12(2), 115-121.

Isaacson, B.(2002). Characteristics and Enhancement of Resiliency in Young People : A Research Paper. Diperoleh 5 Mei 2017 daripada http://uwstout.edu/lib/thesis/2002/2002isaacsonb.pdf

Jenson, J., \& Frazer, M. (2010). Social Policy for Children and Families: A Risk and Resilience Perspective (2nd ed). California; Sage Publication, Inc.

Khabbaz M, Behjati Z, Naseri M.2011. The Relation Between Social Support, Copping Styles and Resiliency In Boy Adolescents. Applied Psychology Quarterly, 108-124 
Kaur, S \& Rani, C (2015).Exploring Psychological Health of Orphan Adolescents: A Comparative Analysis. International Journal of English Language, Literature and Humanities, 3, 27-47.

Mannix, M. M., Feldman, J. M., \& Moody, K. (2009). Optimism and healthrelated quality of life in adolescents with cancer. Child: care, health and development, 35(4), 482-488.

Mohammadzadeh, M., Awang, H., Ismail, S., \& Kadir Shahar, H. (2018). Stress and coping mechanisms among adolescents living in orphanages: An experience from Klang Valley, Malaysia. Asia-Pacific Psychiatry, 10(1).

Mujahidah, E., \& Listiyandini, R. A. (2018). Pengaruh Resiliensi dan Empati terhadap Gejala Depresi pada Remaja. Jurnal Psikologi, 14(1), 60-75.

Napitupulu, C. A. (2009). Resiliensi Remaja Yatim Piatu Di Panti Asuhan Mardi Siwi Kalasan Yogyakarta. (Skripsi). Fakultas Psikologi Universitas Sanata Dharma Yogyakarta: Yogyakarta.

Neill, J.T., \& Dias, K.L. (2001). Adventure Education and Resilience: The DoubleEdged Sword. Journal of Adventure Education and Outdoor Learning, 2, $35-42$.

Nisfiannoor, M. (2009). Pendekatan statistika modern untuk ilmu sosial. Jakarta: Salemba Humanika.

Nurmalita, R., \& Hidayati, F. (2014). Hubungan Antara Regulasi Emosi Dengan Kompetensi Interpersonal Pada Remaja Panti Asuhan. Empati, 3(4), 512520 .

Parke, R.D., McDowell, D.J., Cladis, M., Leidy, M.S. (2006). Family and peer relationship: the role of emotion regulatory processes. Emotional Regulation in Couples and Families, 7, 143-162.

Rifai, N. (2014). Penyesuaian Diri Pada Remaja yang Tinggal Di Panti Asuhan (Study Kasus Pada Remaja yang Tinggal Di Panti Asuhan Yatim Piatu Muhammadiyah Klaten). (Skripsi). Fakultas Psikologi Universitas Muhammadiyah Surakarta:Surakarta.

Shabrina, N. B. U. (2018). Optimisme dan Adversity Quotient pada Remaja Panti Asuhan di Yogyakarta. (Skripsi). Fakultas Psikologi Universitas Islam Indonesia. 
Sun, J., \& Stewart, D. (2007). Age and gender effects on resilience in children and adolescents. International Journal of mental health promotion, 9(4), 1625 .

Tricahyani, I. A. R., \& Widiasavitri, P. N. (2016). Hubungan Antara Dukungan Sosial Dengan Penyesuaian Diri Pada Remaja Awal Di Panti Asuhan Kota Denpasar. Jurnal Psikologi Udayana, 3(3).

Tsuraya, F. H. (2017). Hubungan Antara Resiliensi Dengan Subjective Well-Being Pada Remaja Panti Asuhan Di Kabupaten Banyumas. (Skripsi). Fakultas Psikologi Universitas Muhammadiyah Purwokerto:Puwokerto.

Yendork, J. S., \& Somhlaba, N. Z. (2014). Stress, coping and quality of life: An exploratory study of the psychological well-being of Ghanaian orphans placed in orphanages. Children and Youth Services Review, 46, 28-37. 